\title{
ISSUES AND ACCOMPLISHMENTS IN ADMINISTRATIVE REGULATION: SOME POLITICAL ASPECTS
}

\author{
Winston M. Fick*
}

A general critical examination of the issues and problems of administrative regulation by American government, set against the background of its goals and achievements, may be needed at present.

American experience with administrative regulation by government has been abundant and diverse, and has given rise to a very large and complex body of thought and discussion. But this has, in recent years, dealt mainly with spectacular public issues, such as the controversies over misconduct and inefficiency in the independent federal regulatory commissions, and with quite technical subjects, such as improvement of procedure, and with matters of specialized scholarship. ${ }^{1}$ There are few current attempts at either of two tasks-that of giving a broad perspective view of the subject, and that of providing a general framework of ideas within which to grasp and appraise it as a whole.

These tasks are difficult ones. Their full accomplishment would require adequate foundations of at least four sorts.

One is analysis of the interactions between administrative regulation and the economic structures and economic dynamics of the sectors of the society that such regulation affects. A satisfactory general theory of administrative regulationwhich is the ultimate goal-would have to be grounded upon understanding of these crucial determinants.

Another is appropriately arranged knowledge of the organization and workings of the programs and agencies of administrative regulation. A great deal of knowl-

- A.B. I942, LL.B. I950, University of California (Berkeley); Ph.D. I958, Claremont Graduate School. Member of the California bar. Associate Professor of Government, Claremont Men's College and Claremont Graduate School, Associated Colleges at Claremont.

${ }^{1}$ Much recent discussion of the spectacular issues has centered around the activities of the Special Subcommittee on Legislative Oversight of the House Committee on Interstate and Foreign Commerce, now to be continued as a permanent Special Subcommittee on Regulatory Agencies. I96I CoNG. Q. WEEKLY R. 426 (Mar. 17, I96I). There have been numerous other congressional inquiries on technical matters of administrative organization and procedure, including an invaluable and unfortunately little used one, Staff of House Comm. on Government Operations, 85Th Cong., ist Sess., Survey and Study of Administrative Organization, Procedure, and Practice in the Federal Agencies (Comm. Print i957). The Subcommittee on Administrative Practice and Procedure of the Senate Committee on the Judiciary is conducting a study of several of the various proposals for procedural reform. See its Hearings on Administrative Procedure Legislation, 86th Cong., Ist Sess. (1959), and its Fearings on Federal Administrative Procedure, 86th Cong., 2d Sess. (1960); see also its recent report, Administrative Practice and Procedure, S. REP. No. 168, 87th Cong. Ist Sess. (I96I). There have been many law review articles on technical or specialized matters, and legal scholarship on administrative law has issued in a definitive treatise, KENNETH Culp Davis, Administrative Law Treatise (1958). But political scientists have recently written comparatively little of general application about our subject. It is hoped that the paper will show that there is in the subject much that is of interest and significance for them. 
edge exists (though, of course, we always would like more), but much of it not in forms and categories that make it readily usable for these purposes. ${ }^{2}$

A third lies in the realm of what may perhaps be called causative political analysis, in the study of the forces in the political order that affect administrative regulation.

A fourth is evaluation against normative political standards-against the values and criteria generated by systems of political beliefs.

The present paper is an attempt to make some preliminary contributions to the third of these foundations, to formulate views on political forces that act on the institutions and processes of administrative regulation. ${ }^{3} \mathrm{~A}$ few opening observations may help orient our inquiry and clear the ground for it, since they embody ideas on which it is principally based.

First. A generally acceptable formal definition of administrative regulation would be hard to devise. But perhaps most would agree that we have administrative regulation when we have a regulatory scheme in which substantial discretionary authority, including authority to determine private rights and duties under the scheme, is given to administrative officials, and they have some authority to give their determinations legal effect but are required by law (and perhaps ultimately by constitutional principles) to act within a framework that reduces their freedom to less than that clustered immediately around the politically-responsible executive. ${ }^{4}$

Second. Administrative regulation, when viewed in these terms, is seen to be a very widespread phenomenon and a very much used tool of government. It is to be found in all manner of governmental entities, ranging in size from the largest undertakings recorded in the United States Government Organization Manual down to the smallest local planning commissions and beyond, and also ranging widely in form far beyond the agencies whose sole business is regulation. We have, therefore, a

\footnotetext{
${ }^{2}$ A great deal of it is found in the vast literatures on administrative law, on public administration, on issues of regulatory policy, and on specific agencies, programs, and regulated activities. These literatures are not generally oriented toward administrative regulation, per se and as a separate subject.

"In the present paper, "politics" and "political" are not meant to convey any undertone of disparagement (as "politician," say, often does), but rather merely to refer to the contentious and more dynamic aspects of government.

"This formulation deliberately leaves "regulation" undefined, and simply adopts the broad and shifting meaning of that term given by ordinary usage. (It, of course, covers much more than just regulation of industry.) A classic and infuential work distinguished between "regulation by law," or "statutory regulation," in which substantially all the rules are laid down and the significant determinations are made by statute, with any nonlegislative interpretation and application being done largely by the courts, and "administrative regulation," wherein the statutory framework is less specific and officials are given powers to develop and apply it. John Dickinson, Administratrve Justice and the Supremacy op LAW IN THE UNITEd STATES xi, Io n.I5, and c. I (1927). His example of administrative regulation is a statute of William and Mary directing the justices of the peace to fix rates for common carriers in their parishes. Another distinction often made is between administrative regulation of an industry and regulation by the market, or by statutes enforced directly by litigation without the intermediacy of administrative officials, such as parts of the antitrust laws. See, e.g., George W. Stockinc \& MYron W. WatKIns, Monopoly aNd FreE ENTERPRISe 520-29 (I95I). Our formulation makes a distinction between administrative officialdom and the zone of true executive power and political responsibility; there are not only vital legal differences, but also differences in the institutions and in the forces involved that are exceedingly significant for the present inquiry.
} 
very large subject to talk about. But it is also one whose defining characteristics give it a central core, common to all of its manifestations, to which analysis should be able to lead us.

Third. A key to such analysis is that these characteristics signal the presence of political power and political tasks..$^{5}$ Administrative regulation can be, in part, a technical or ministerial function. But because it has the discretionary official authority that it has, it is also always, in part, genuine government as well.

\section{General Features}

Analysis can well begin with some general features of the background of administrative regulation and of its present condition.

Our first point is that administrative regulation in the United States has a large history, and broad and deep roots.

It is often dated from the era of the Granger movement, the Cullom Committee report, ${ }^{8}$ and the establishment of the state railroad commissions and the Interstate Commerce Commission, at the earliest. And we often tend to think that it was of rather minor importance in government as a whole before the New Deal.

As has frequently been pointed out, both these views are inaccurate history. ${ }^{7}$ The important point for the present inquiry, however, is that they can mislead by blinding us to the fact that the issues and problems, and the goals and achievements, of administrative regulation are very deeply embedded in long-established structures and processes of American government. So blinded, we tend not to look for the more basic causes and determinants in our subject, and to stop analysis with what may often be only transient phenomena of the current scene.

It is also common to see administrative regulation as, in the main, the work of the independent federal regulatory commission, and otherwise to conceive of it as rather narrow in scope.

The commissions probably do and have done only a rather small part of the total amount of administrative regulation done even by the federal government, and the periods of eclipse to which the commissions are subject have not by any means always been periods when administrative regulation as a whole declined drastically in

\footnotetext{
The nature and use of the concept of power has been the subject of much scholarly controversy. The meaning herein is much the same as that of common usage, and includes authority and influence.

${ }^{-}$Senate Select Comm. on Interstate Commerce, Report upon the Subject of the Transportation of Freights and Passengers between the Several States by Railroad and Water Routes, S. REP. No. 46, 49th Cong., Ist Sess. (1886).

"See, e.g., Attorney General's Comm. on Administrative Procedure, Administrative Procedure in Government Agencies, S. Doc. No. 8, 77th Cong., Ist Sess., c. I (I941); Leonard D. White, The Federalists (1948), The Jeffersonians (1951), The Jacksonians (I954), and The Republican Era, I869-IgOI (1958) for the federal level. Much of general background as to regulation of business is summarized in Merle Fannsod, Lincoln Gordon \& Joseph C. Palamountain, Jr., Government and the American Economy passim (3d ed. 1959). See also the materials in Lloyd M. Short, The Developaent of National Administrative Organization in the United States (ig23).
} 
scope or in vigor or in importance in government. ${ }^{8}$ Wartime periods (especially, of course, that of World War II) have been periods of great expansion of administrative regulation and of far-reaching permanent developments and changes in it, yet are often almost omitted from discussions of it. ${ }^{\ominus}$ And finally, there has clearly been very extensive, diverse, and significant experience with it in state and local governments, but comparatively little of this experience has been made readily accessible or is considered in general writing and discussion. ${ }^{10}$

All in all, then, the impressions are strong that there are shadowed and neglected areas, outside the usual zone of attention, and that matters of importance for both the practice and the study of our subject lie in them.

Our second point moves to a more specific question. Is it possible to point to a time when influences, from history and elsewhere, seem to have come to some focus, to have produced the beginnings of the current era of administrative regulation, the present system?

Evidence on the question is largely impressionistic, and any answer must be conditional; perhaps seldom can the location of such divides in political affairs be established with cadastral positiveness. But in almost every strand of administrative regulation we trace back - structures, processes, subject, technique, ideologies, etc.-

\footnotetext{
${ }^{8}$ Measurements of the scope, volume, and importance of administrative action generally are notoriously
} slippery matters, see, e.g., I Davis, op. cit. supra note I, C. I; and the difficulties do not decrease as one attempts to refine the measurements to types of administrative action, such as administrative regulation, and to extend them back in time; the problems of classification and of availability of data are both almost insoluble. Thus, the statistics of what would seem to be a natural source of recent federal data, the annual reports of the Office of Administrative Procedure of the Department of Justice, cover only proceedings in which opportunity is afforded for hearing before an Administrative Procedure Act $\$$ II examiner, see, e.g., Office of Administrative Procedure, Office of Legal Counsel, U.S. Dep't op Justice, Third ANn. Rep. Io (1959); and in the nature of things do not measure importance. The conclusions we state are, therefore, impressionistic, but they do seem to emerge quite clearly as one looks over the field.

${ }^{\circ}$ Histories, some official and some not, of various wartime agencies and programs have been published. Some efforts to apply wartime experience in drafting later statutes are recorded. E.g., Field, Economic Stabilization Under the Defense Production Act of 1950, 64 H^rv. L. Rev. 1 (1950). Scholars have sometimes drawn on their individual experiences in government service in wartime. E.g., Charles Hyneman, Burenucracy in a Democracy (1950). But it is not customary to take much explicit account otherwise of war periods and their effects. Indeed, lack of the historical scnse is very widespread in thought on our subject, even though history has very greatly influenced the subject itself.

${ }^{10}$ There are a few standard studies, such as Robert M. Benjamin, Administrative Adjudication in the State of New York (1942); James W. Fesler, The Independence of State Regulatory Agencies (I942); Ferrei Heady, Administrative Procedure Legislation in the States (ig52); and some other treatments of specific problems. There is a considerable literature on state administrative law. See, e.g., the citations in Davis, op. cit. supra note 1 . There is a very large literature on state government, of course, especially on state public administration; this contains much material on administrative regulation, but this material is largely buried in other categories and approaches and hence is little used in thought on the subject. There may, however, be an increasing current flow of special studies, written from the viewpoint of administrative regulation, of state agencies and programs. E.g., Note, The Regulation of Advertising, 56 Colum. L. Rev. I018 (I956); Note, The Right to Equal Treatment: Administrative Enforcement of Antidiscrimination Legislation, 74 HARv. L. Rev. 526 (1961); Note, State Administrative Practice: An Illustrative Survey of the Procedure of the Massachusetis Department of Public Utilities, 67 Harv. L. Rev. 845 (1954); and Note, Pressures in the Process of Administrative Decision: A Study of Highway Location, 108 U. PA. L. REv. 534 (1960). And occasionally one encounters a general formulation relevant to our subject that is based on state materials. E.g., Boycr, Policy Making by Government Agencies, 4 Midw. J. PoL. Sc1. 267 (1960). 
some sharp touch of novelty, some significant new configuration, appears somewhere in the early New Deal days of the I930's, even though there also are, at least as frequently, profound continuities across those years to the remoter past. With allowances for such continuities and for the difficulties of any division, our inquiry can emphasize the period that seems to have begun then.11

But even if the period is a period, an entity we can separate in meaningful ways from what went before, is it now about complete? Do we now have before us the more or less complete life histories and the mature, fully-developed forms of its phenomena?

This is a difficult question, but it is one that any general critical examination of administrative regulation encounters. A full answer based on any thorough review of all the evidence would be a vast undertaking, and perhaps an impossible one until we have a longer historical perspective. The following is merely a single observation, but it is one on what may be a central point. There seem to have been few really basic new ideas and approaches evolving in recent years in the established and generally accepted body of thought about either the practice of administrative regulation or its study. This is not at all to say that administrative regulation is stationary or declining in importance, scope, or number of uses. Indeed, it is probably rising in all these respects. ${ }^{12}$ But as one follows discussion and the literature and at least the general aspects of the practice, one seems to encounter comparatively little that goes beyond the conceptual frameworks of five, ten, or even twenty years ago. Exceptions and embryonic new departures certainly exist, and some are mentioned later in this paper. And, of course, new periods of development and innovation lie in the future. But the period of creativeness that began in New Deal days appears now to have pretty much run its course. ${ }^{13}$

Our third point concerns one result of the events and controversies of this period. They seem to have brought quite substantial amounts of consensus into the general body of thought on administrative regulation.

In New Deal days, and for some time thereafter, this thought was dominated and deeply divided by extreme, rigidly held, and largely incompatible viewpoints, all maintained by warlike factions, each believing itself in possession of a nearly

11 This conclusion, like those on the place of the independent regulatory commission, supra note 8 and accompanying text, is hard to document; and like them, it can only be offered as a strong impression.

${ }^{19}$ Here it seems possible to collect more concrete evidence than for the conclusions discussed supra note 8. Most regulatory agencies and programs seem to be expanding as fast or faster than government generally, and it is difficult to find many that have been abolished or much reduced since, say, the end of the Korean War. New ones keep appearing. See, e.g., those to enforce antidiscrimination legislation, Note, The Right to Equal Treatment: Administrative Enforcement of Antidiscrimination Legislation, 74 Harv. L. Rev. 526 (I96I); and the recent developments in regulatory activities by the $A E C$ in reactor licensing, and by the Food and Drug Administration under the Food Additives Amendment of 1958,72 Stat. 784,21 U.S.C. $\$ \S 321,342,346,348$ (1958), and the Color Additives Amendments of I960, 74 Stat. 397, 21 U.S.C.A. $\$ \$ 321$ et seq. (Supp.). Examples could be multiplied by examining the legislative output of any recent session of Congress (and probably of most state legislatures).

${ }_{13}$ These points are discussed, and some evidence for them is offered, infra pts. II and IV. 
absolute and nearly sufficient truth. ${ }^{14}$ The extreme hopes and the extreme fears, however, have alike been disappointed. The more violent of the old polemics now seem dated. ${ }^{15}$ The harsh outlines have softened. All views are not yet fully in harmony by any means, but they are much closer together now than they were in the old days. ${ }^{16}$ There is now much more eclecticism and much more moderation and compromise. Theses and policies are now usually stated in less rigid and allencompassing form.

Things are probably not ripe for the construction of a single grand general theory-if, indeed, they ever will be. But we do seem to see the strands of a chapter in the history of our subject drawing together into a synthesis and final statement, so that the formulation of a general critical view of it is possible. ${ }^{17}$

14 Conservative, antireform, and anti-New Deal thought generated much intense opposition to all administrative action, including administrative regulation. For treatments of aspects of such thought for various periods, see Thomas Cochran, The American Business System (1957); James W. Prothro, Doltar Decade (1954); and Francis X. Sutton, Seymour E. Harris, Cari Kaysen \& James Todin, The American Business Creed (I956). For an analysis of the political theory of some major anti-New Deal viewpoints in the r930's, see Thomas P. Jenkin, Reactions of Major Groups to Positive GovernMENT IN THE UNITED STATES, I930-1940 (I945). The core of the thought was, of course, a nearly absolute faith in unalloyed private enterprise. Legal formulations of it are found in abundance, especially in the American Bar Association publications of the period. Opposing viewpoints included those that clustered around an almost equally absolute faith in government planning and broadly discretionary government power as the cures for the social ills of the time, those based on various doctrinaire reform movemerits, and those of the public administration movement, which is discussed briefly in the next part of this paper.

${ }^{15}$ E.g., JaMres Beck, OUR Wonderiand of Bureaucracy (1932). And few, even among the new conservatives, would now urge that the following 1943 statement by Herbert Hoover embodies a tenable theory of government: "When Governments exert regulation of economic life, they must do so by definite statutory rules of conduct imposed by legislative bodies that all men may read as they run and in which they may at all times have the protection of the courts." Quoted in Leventhal, Book Review, 68 YALE L.J. 614 (1959). Similarly, the extreme arguments for planning and the extreme claims for what could be achieved by free administrative action would find little support now even among unreconstructed New Dealers. See also the bitter controversy over the Administrative Procedure Act of 1946, 60 Stat. 237, 5 U.S.C. $\$ \S$ IOOI-II (I958), and over the various legislative events that led up to its enactment. This was perhaps one of the last full confrontations of the various extreme viewpoints before moderation set in. The Act was rather limited in purpose and effect. See, e.g., Parker, The Administrative Procedure Act: A Study in Over-Estimation, 60 YALE L.J. 58I (195r). Yet, some of the criticisms of it, e.g., Blachly \& Oatman, Sabotage of the Administrative Process, 6 PuB. Admin. Rev. 213 (1946), were quite intemperate, as were also many of the arguments for it.

${ }_{18}$ There is still a good deal of suspicion among advocates of the administrative process of proposals that are deemed likely to constrain or formalize that process. See the criticisms of the American Bar Association's proposed Code of Federal Administrative Procedure in Heady, The New Reform Movement in Regulatory Administration, r9 Pub. Admin. Rev. 89 (1959). The Code was generally received with, at best, great reserve and more often with unbridled hostility by the federal departments and agencies, as reflected in their comments on it filed with the Senate Judiciary Committee in 1959-60, when it was introduced as proposed legislation, S. 1070, 86th Cong. Ist Sess. (1959). Actually, the Code is a rather moderate proposal. Sce, in this connection, the comments on Professor Heady's views in Rosenblum, Public Administration and Public Law: Mutual Perspectives in Regulatory Agencies, a paper delivered at the 1959 convention of the American Political Science Association. And the agency criticisms are largely unfounded. See Leo A. Huard, Rex A. Collings, Jr. \& Winston M. Fick, A Study or Agency Comments on the Proposed Code of Administrative Procedure (ig6i), a study prepared for the ABA's special committee on the Code. Yet, at one time, the ABA was a center of extreme opposition to the whole administrative process; the change in its viewpoint is a striking illustration of the new state of affairs.

${ }_{17}$ Though any such undertaking inevitably involves some drastic simplifications as well as a great deal of selection. 


\section{Some Ideological Elements}

An examination of the goals, achievements, issues, and problems of administrative regulation is inevitably an examination, at numerous levels, of what we may loosely term its ideological elements-the ideas, values, concepts, views of government and society, and the like on which it is based. These determine the goals, direct the achievements, and define the issues and problems, within the broad limits set by social and technological conditions and by the general framework of the political order.

Thorough examination of these ideological elements would require virtually a complete intellectual history of thirty years of the practice of American government. Mention is made here only of a few, chosen almost arbitrarily from the many that now appear to have been especially important.

No one list of such elements would ever command universal agreement, but the following would probably appear on most lists: (I) a strong and pervasive faith-albeit a faith that has faded somewhat in recent years-in "expertise," in the existence of the solutions to public problems and the discoverability of these solutions through the application of special knowledge and skills; ${ }^{18}$ (2) a challenge, under the banners of sociorealist juristic theory, to some of the established views of the nature of law and of the judicial function $;^{19}$ (3) the doctrines of the public administration movement and the ideas behind those doctrines; and (4) a thread woven through almost the whole fabric of thought, and exceedingly difficult to grasp and appraise, which perhaps can best be labeled as the concept of "the administrative process."

The latter two of these particularly require some comment here.

At least by middle New Deal days, the public administration movement ${ }^{20}$ had become established as a major influence in government. This occurred partly because the movement had built up a record of substantial accomplishments, partly because its theses were appealing in the circumstances and its spokesmen were devoted and effective advocates, and partly because it was one of the few move-

18 This was naturally a doctrine of the public administration movement, but it was also much more widely held. See, e.g., the article, Expert in 6 ENcyc. Soc. ScI. 1o (193I), for some hints of this.

10 "Sociorealist" is used as a broad (and, of course, loose and somewhat imprecise) term to refer to the areas of agreement of legal realism, sociological jurisprudence, and related schools, and to contrast these with the then-traditional analytic, "mechanical," positivistic jurisprudence. With individual exceptions, exponents of the former tended to be ranged on the side of "the administrative process" and to be relied upon by its advocates, whereas the latter was the doctrine of its opponents. An analysis of the juristic theory of one of the most influential and typical pro-administrative books of the period, James M. Landis, The Adminisrantive Process (1938), is Chroust, Law and the Administrative Process: An Epistemological Approach to Jurisprtedence, 58 Harv. L. Rev. 573 (1945).

20 Any description of the movement and its thought would certainly include references to two of its basic texts, Leonard D. White, Introduction to the Study of Administration (1926), and Luther Gulick \& Lindall Urwick (Eds.), Papers on the Science of Administration (1937). The leading historian of the thought of the movement is Professor Dwight Waldo. See Dwigrt Wazdo, The Administrative State (1948), The Study of Public Administration (1955), Development of Theory of Democtatic Administration, 46 AM. PoL. ScI. Rev. 8I (1952), Administrative Theory in the United States, 2 Pol. Studies 70 (I954), and Perspectives on Admistration (1956). 
ments on the scene that offered a program and technique for constructing and operating the big government that the political situation was producing. Professor Waldo has shown, in a classic study, that the movement propounded, explicitly or by implication, answers to several of the great problems of political philosophy. ${ }^{21}$ At least three of these are crucial in administrative regulation, and the influence that parts of the movement's answers had on it was substantial.

To the question, What is the good society?, the movement answered (in part): One in which environment has been fully mastered for man by extensions of scientific method, in which planning rationally apportions the society's available means among chosen ends, in which the choice of ends is by public mechanisms and standards rather than laissez faire, and in which individualism, materialism, and egalitarianism are strong.

To the question, What should be the criteria, the bases, for decision and action on public matters?, the movement offered a compound from utilitarianism, positivism, and pragmatism.

To the question, Who should rule?, the movement returned an answer made somewhat ambiguous and incomplete by obscurities in its idea of a general expertise in government and by some hesitation to think the matter through, but an answer that granted the administrator a large claim upon the exercise of political power.

Add to these the movement's very great influence on more specific and lowerlevel matters, such as organization, management, and technique, ${ }^{22}$ and we have a substantial part of the ideological structure of our subject not only in its New Deal days, but long after. ${ }^{23}$

The phrase "the administrative process" was apparently established in general use by Dean Landis's famous book and by the report of the Attorney General's Committee on Administrative Procedure. ${ }^{24}$ A group of similar phrases developed: the legislative process, the regulatory process, the political process, the decisionmaking process, etc. The common parent probably was "the process of government," used by A. F. Bentley. ${ }^{25}$ All revolve around the central concept of a series

${ }^{21}$ Dwight Waldo, The Administratrve State (1948). "Political philosophy" is perhaps most accurately regarded as the part of a political theory devoted to a general philosophical rationale of moral foundations, to questions of "ought." Thomas P. Jenkin, THE STUDY of Political Theory 6-II (1955). But as Professor Waldo shows (and as Herbert A. Simon, Administrative Behavior (i947), has emphasized), the "is" and the "ought" have been much intertwined in thought about public administration.

${ }^{23}$ That is to say, its influence was felt not only through its ideas on the grand issues of political ideals and its contributions to its own special field of asserted competence, the actual mechanics of government, but in between, in the middle range, through, for example, its emphasis on "cconomy and efficiency," on rationalized (and mainly hierarchical) organizational structures, and on its idea that "administration is a single process, substantially uniform in its essential characteristics wherever observed," Leonard D. White, Introduction to the Study of Administration preface (1926); and through its devotion to what it took to be scientific method and hard facts.

${ }^{23}$ Indeed, long after the movement itself had abandoned or modified many of its own views.

${ }^{24}$ Landis, op. cit. supra note 19; Attorney General's Comm. on Administrative Procedure, stupra note 7, c. I, "The Origins, Development, and Characteristics of the Administrative Process."

${ }^{25}$ Arthur F. Bentley, The Process of Government (1908). Bentley was highly regarded in the 1920's and 1930's by the influential "Chicago school" of political scientists and those close to it, long before his recent revival. Bernard Crick, The American Science of Politics c. 7 (1959). 
of continuing functional interrelationships and interactions. ${ }^{26}$

As a tool or weapon in the hands of practitioners, and as an analytic device in the hands of students, of administrative regulation, the concept in all its various formulations released much new energy in many new directions. In particular, it seems, as we look back, to have been intimately connected with the stunning dynamism that characterized so much of our subject in the midpart of the period. ${ }^{27}$

Its importance arose, in part, from the fact that it points toward a central characteristic of government, continuousness and interrelatedness flowing across the lines of governmental institutions and structures and of legal-constitutional categories. This characteristic is peculiarly significant for administrative regulation, and it is one that the advocates of the concept believed to be both the channel of the energizing forces that make the institutions and structures work and also the reality that underlies the categories. ${ }^{28}$

Another basis for the concept's importance is a matter of personalities; it became one cornerstone of the doctrine of a host of energetic and imaginative new practitioners and students who were then rising to power. To them, it was one key to escape from the traditional arrangements and methods with which they were dissatisfied, and they used it to the full.

The concept and the associated characteristic of government have another dimension of meaning for the present inquiry besides the help they give in elucidating the intellectual history of our subject. One of the principal achievements of American administrative regulation has lain in the rather high degree to which it has made itself responsive to this characteristic, to continuousness and interrelatedness across organizational and categorical lines; indeed, such responsiveness is close to the heart of the ideal and the tradition of performance that have flowed from the Landis book. And one of the basic and continuing groups of problems is that of what is the proper extent and the proper forms of such responsiveness in particular situations. This question lies behind numerous current concerns about administrative regulation, such as those about "judicialization," agency independence, policy development, relations with regulated interests, and the like. ${ }^{29}$

Moving now to the present scene, can we discern any movements in contemporary thought that are now providing, or are likely soon to provide, significant new ideological elements for either the practice or the study of administrative regu-

\footnotetext{
${ }^{26}$ A brief discussion that has the tone of the advanced and sophisticated sectors of the thought of the time is Fainsod, Some Reflections on the Nature of the Regulatory Process, in CARI J. FRIEDRICH \& Edward S. Mason (Eds.), Public Policy 297 (I940).

${ }^{27}$ As one rereads the records of the time, one is struck by how often the phrases appear. The concept seems to have been almost constantly in the minds, sometimes explicitly and sometimes unrecognized, of the men who were leading all the innumerable new ventures in government.

${ }^{28}$ Thus, the reality was seen as a seamless web (if one may misapply that famous phrase), and it was felt that the rigid divisions were mistaken deductions from the doctrine of separation of powers and from the legal-structural approach.

${ }^{20}$ For example, judicialization tends to reduce responsiveness generally, and independence tends to reduce it as to forces flowing through the Presidency but (usually) to increase it as to forces flowing through Congress.
} 
lation? Obviously, this question also is extraordinarily broad, and any answer can only be a limited and partial one, but a comment or two must be hazarded.

We have already suggested that established present-day thought in our subject does not seem to be very imaginative or creative; indeed, even the leading reform proposals go little beyond the conceptual framework of, say, the report of the Attorney General's Committee of $194 \mathrm{r}^{30}$ Elsewhere, however, there are movements in thought that have some strikingly novel things to say. These are not limited to academic scholarship, but they are concentrated there. Although they are already exercising considerable influence on the practice of government in other fields, they have so far barely touched administrative regulation as such. But there has always been much exchange between academic scholarship and the practice of administrative regulation, and no doubt there will be much in the future.

One group of such movements may be selected for brief description and comment. ${ }^{31}$ It is the group associated with what may be called, as a rough catch-all designation, modernism in the social sciences, and in particular with what is usually denominated "the political-behavior approach" to the understanding of government and politics.

The political-behavior approach has been authoritatively described as having four distinguishing characteristics, among others. (I) It takes as its unit of study the behavior of persons and groups, not events, institutions, or ideas. (2) It is close to the behavioral sciences, notably psychology and sociology. (3) It emphasizes the interdependence of theory and empirical research, seeking both to formulate theoretical questions to guide research and be tested by research and also to apply research results explicitly to the development of theory. (4) It is interested in precisely formulated research hypotheses and in rigidly empirical verifications, by observation almost always and by measurement whenever possible. In each of these, one sees possibilities of valuable new tools for practitioners and students of our subject alike. Furthermore, some such possibilities have already been realized. ${ }^{82}$

A great deal is known about the events, institutions, and ideas of administrative regulation. About the actual behavior of the actual people who regulate and are regulated much less is known, and most of that is intuitive and unsystematic, based upon practical experience rather than explicit study, and hence not readily communicable. The student or administrator of any regulatory agency probably could use much more of the sorts of information the new approach can supply, such as: what are the actual channels of effective communication within the

${ }^{30}$ That is to say, they tend to talk the same language and think in terms of the same ideas, even though the problems they see, and their specific views and conclusions, often differ widely from those of the Committee.

${ }^{31}$ There are numerous others, such as (I) the case studies of administrative processes being done for the Inter-University Case Program and by a research group headed by Professor Marver H. Bernstein of Princeton; (2) the new work by economists in industry studies and in' the effects of regulation; and (3) the very rapid developments in the study of organization and of administration.

82 The description is paraphrased from Heinz Eulau, Samuel J. Eldiersveld \& Morris Janowitz (Evs.), Political Behavior 3-4 (1956). This book is usually regarded as a basic text, and a leading programmatic statement, for the approach. 
agency; what would be an accurate cross-sectional picture of contacts between the regulated and agency personnel; and what are the informal organizations within the agency, and what functions do they perform. Questions could be multiplied, and each answer would add some new dimensions to what can be learned by orthodox methods of inquiry. ${ }^{33}$

Attitudes, values, images, roles, and other components of human relationships and motivations surely affect decisively the actions of people involved in administrative regulation. Exploration of these with the techniques of psychology and sociology can shed much light. For example, something is now known about the sociopsychological conditions of effective regulation of businessmen. ${ }^{\mathbf{3 4}}$

The commitments of the political-behavior approach to close and reciprocal interactions between theory and empirical research, and to more nearly scientific standards and techniques of verification, present more difficult problems. On the one hand, most people interested in administrative regulation would agree on the desirability of these in general and on many specific situations in practice and study where they would be exceedingly relevant. However, there would be doubts whether the material of our subject would lend itself to them and whether the typical politicalbehavior research design can be sufficiently broad to encompass a meaningful question about the regulatory process. But perhaps the overriding fact is that there can be little doubt of the value of the approach's theory-research and methodologyverification views for shaking up established thought, pushing it toward new insights, and making it ask new questions and see new dimensions. ${ }^{35}$

\section{III}

\section{The Place of Administrative Regulatron in Government}

We now turn to one of the most important general questions about administrative regulation, and one that was the subject of very stormy controversy during much of the period we are considering: What is its place with respect to the great agencies of government-the legislature, the executive, and the courts ? ${ }^{36}$

This question is only partly answered by facts about magnitudes and functionshow much, and what, administrative regulation has done-and by discussion of the constitutional considerations involved. Knowledge is also needed about the causes that have determined the structural and functional relationships. Looking back on the American experience in our period in the light of modern thought, it seems

s3 This is not to say that the orthodox methods do not develop information on behavior, but merely that the explicitly behavior-oriented methods would often develop more, and from different angles.

at Robert E. Lane, The Regulation of Businessmen (I954).

${ }^{25}$ Surely one of the best actual examples of this is the effect the approach has had on public administration.

${ }^{30}$ Putting the question in this form asserts that the classic separation-of-powers categories are significant ones and, further, that there is a real division between the administrative and the executive proper. These two hypotheses are defended, by implication, in what follows. 
possible to make some broad statements on these relationships and their causes with considerable confidence. A few such are now offered and briefly discussed. ${ }^{37}$

I. At the heart of the whole matter lie the tensions permanently present in American government because of the doctrine of, and constitutional arrangements for, separation of powers. This is commonly recognized, but a crucial implication often is not. The tensions, permanently present, are also constantly working and changing, in an unending process of interaction and transformation, and are never still. Assertions about the nature and characteristics of the place of administrative regulation must, therefore, take careful account of this process. The structural and functional relationships between administrative regulation and the other parts of government are largely created and continuously remoulded by, and are principal battlegrounds for, the profoundly political forces of the great struggles for power. ${ }^{38}$ Thus, when a conflict occurs over removal of a Federal Trade Commissioner, ${ }^{30}$ or over "legislative oversight,"40 or over "executive leadership," or over "judicial supremacy," or over judicial review of administrative action in which the President has participated, or over most of the innumerable other issues or relationships, we are, in substantial part, simply seeing a permanent element in our constitutional and political system operating. ${ }^{41}$

2. Intertwined with these tensions, deep in the foundations of administrative regulation, and perhaps rivaling these in importance, are the consequences of another fact: administrative regulation is government in small. A cross-section of almost the totality of the tasks and incidents of governments and politics is created (or assembled) when an agency or program of administrative regulation is established; it is a political enterprise with political goals, as well as a piece of technical and bureaucratic machinery. ${ }^{42}$

\footnotetext{
${ }^{87}$ For convenience, they are put as a series of numbered propositions. However, it is not claimed that these propositions form, or are based on, a complete theory. Nor are they intended to involve more than the most minimal assertions about what the proper place of administrative regulation should be.

${ }^{38}$ On this, as on so many aspects of American government, the Federalist continues to be profoundly enlightening. See, e.g., Nos. 10, 47-49, and 51 .

${ }^{30}$ Humphrey's Executor v. United States, 295 U.S. 602 (x935). And see Weiner v. United States, 357 U.S. 349 (1958); and congressional reaction to President Kennedy's Feb. 7, 1961, letter asking for reports from the commissions. xo7 CoNG. Rec. 3686-88 (daily ed. Mar. 14, 1961).

${ }^{10}$ The phrase originated in the heading to $\$ 136$ of the Legislative Reorganization Act of 1946 , which directs each standing committee of Congress to "exercise continuous watchfulness of the execution by the administrative agencies concerned of any laws, the subject matter of which is within the jurisdiction of such committee. . . ." 60 Stat. 832, 2 U.S.C. $\$ 190 d$ (1958); cf. H.R. Rule XI-27 (1959). The Constitution directs that the President "shall take Care that the Laws be faithfully executed." U.S. CoNsT. art. II, $\$ 3$.

"See, e.g., Hochman, Judicial Review of Administrative Processes in Which the President Participates, 74 HaRv. L. Rev. 684 (I96I).

${ }^{12}$ Thus, Professor E. Pendleton Herring, in Public Administration and the Punlic Interest 6-16 (1936), had already remarked on how parts of the legislative and political task of reconciliation have been, and have had to be, shifted to the administrative. Groups subject to agency regulation generally see its political aspects very clearly, but there seems to have been a certain hesitation about studying the agencies in a thoroughly political light; perhaps this was a consequence of the now-discarded vicw that there is a basic difference between politics and policy-making and administration. See, on this, Dwiour Wardo, The Administrative State c. 7 (1948).
} 
Many of the characteristics of administrative regulation, including many of its achievements and certainly a very fair share of its issues and problems, arise from this fact and from the further fact that it typically has few of the institutions and traditions of politics to help it. Politics involves struggles over political power with political weapons-popular support, pressure, polemics, and the like; it involves negotiation, reconciliation, compromise, the generating of consensus; it involves the resolution of some of the keenest and most serious conflicts a society produces. Normally, this goes on in a broad setting, and through a complex of large and explicitly political institutions and traditions: legislatures, campaigns, parties, elections, deals, etc. In a typical system of administrative regulation, however, it goes on in a microcosm, under distorting restrictions, centered around a government office that purports to be a chaste bureaucracy like any other, and with hardly any recognized and approved political (or even quasi-political) devices available to ensure that it will have light, air, and structure and will work efficiently and in accordance with the society's accepted rules for conduct of the political struggle. ${ }^{43}$

It is, therefore, not surprising that there have been half-explicit and halfrecognized tendencies, scattered throughout our period and embodied in many specific instances, for some such devices to develop-for example, for administrative rule-making to acquire some of the give-and-take openness of the legislative process, and administrative adjudication some of the insulation of the judicial, and for agency commissioners to function through their political rather than their technical abilities. Nor is it surprising that activities around regulatory agencies and programs have so frequently burst their bounds and appeared as full-fledged political wrangles in the legislature; this is inevitable and natural, is not an accident, and is still less an anomaly or distortion. . $^{4}$

3. Congressional power over, and participation in, administrative regulation has turned out to be, in substantial measure, (a) constitutionally sound, (b) a product of some of the basic facts of our political order, and (c) inevitable.

Relations between Congress and the administrative were debated, and sometimes fought over very bitterly, almost continuously during our period. The assertion was heard frequently from congressional quarters that not only is there virtually nothing in any administrative or executive activity, excepting a few specific personal functions of the President, that is immune from congressional examination, but also there is virtually no administrative action that Congress or its committees cannot control-indeed, could not do themselves if they had a mind to. ${ }^{45}$ Opposite ex-

\footnotetext{
${ }^{43}$ Many of the devices exist and are, of course, used, but not officially, and they are usually under some degree of cloud.

"Proposals for reform of the administrative process now seem more and more to be recognizing all of this.

¿5 This is still a favorite theme of congressmen questioning regulatory officials. See, e.g., the panels held by the Special Subcommittee on Legislative Oversight of the House Committee on Interstate and Foreign Commerce in its Hearings on Administrative Process and Ethical Questions, 85th Cong., 2d Sess. (1958), and Hearings on Major Administrative Process Problems, 86th Cong., Ist Sess. (1959).
} 
tremes were urged by spokesmen for the administrative viewpoint. ${ }^{40}$ This warfare along the marches will no doubt go on as long as the governmental system retains its vitality, but the experience of the last twenty-odd years suggests at least a few conclusions about some fundamental aspects of the matter.

Both in constitutional doctrine and also in the actual functioning of the constitutional order, with which we are here more directly concerned, quite extensive congressional power and participation seem sound, in the sense of being workable and consistent with the nature of the structures and processes involved. ${ }^{47}$

Experience also seems to have made it clear that the causes of congressional participation and the sources of congressional power lie in some measure in basic political facts. Congress is the channel through which important portions of the energies of popular sovereignty and representative government flow, and it is the instrument by which (and the arena in which) there is determined most public policy lying in the middle range between the very general and the very specific. It is, therefore, pushed from many quarters into intervention in administrative regulation and is equipped with the political power to intervene effectively. And a vital category of specific forces works in the same direction; operation through Congress is a natural recourse for interest groups striving either to get their way with reluctant regulators or to assist and support favorable regulators. ${ }^{48}$ With these and many other forces almost constantly in operation, and with few major counterforces, it seems safe to speak of such intervention as inevitable. ${ }^{49}$

4. On the other hand, numerous congressional efforts at participation or control, falling into several fairly definable classes, have not been successful. Some of the causes of this have also to a considerable extent emerged, and it now seems possible to say that limits on the congressional power do exist, and even to describe them a little-matters of much importance to a general view of administrative regulation. ${ }^{60}$

First, consider situations where there has been serious agency resistance. Congressional attempts at participation and control have on numerous occasions run into grave difficulties when met with such resistance. There have, for example, been a number of instances in which congressional groups have been unable to get data from agencies or full access to their internal affairs, unable to compel some agency

\footnotetext{
${ }^{48}$ Largely as a part of the disillusionment with Congress, and the trust in presidential leadership, so widely felt in the I930's. Congressional handling of the tariff is an example of the causes of this disillusionment. See Elmer E. Schattschneider, Polttics, Pressures, and the Tariff (1935).

${ }^{47}$ A thoroughgoing defense of this view, based on acute political analysis, is Newman \& Keaton, Congress and the Faithful Execution of the Laws-Should Legislators Supervise Administrators?, $4 \mathrm{I}$ Car.rF. L. REv. 565 (1953), although, as these authors, of course, point out (and demonstrate in their remarkable collection of facts and authorities), there are limits.

${ }^{48}$ Examples are innumerable. Indeed, the existence and importance of almost continuous reciprocal interactions among legislature, administrative, and interest groups is now a truism in the study of government.

${ }^{\circ}$ It is, in fact, difficult to point to specific agencies or programs in which such interventions and the consequent further interactions do not appear to be going on, to some degree, almost all the time.

${ }^{50}$ Especially for one that seeks to approach the matter from the standpoint of politics and power. The general subject is discussed, and some material collected, in Roland Young, The American CONGREss cc. 7-IO (1958), and, from varying points of view, in most other studies of Congress.
} 
actions, and unable to change agency policies or prevent these from being carried out. ${ }^{51}$

Sometimes the reasons for such outcomes have been adventitious; participants on the congressional side have lost interest or have decided it would be undesirable to press matters, the White House has intervened, etc. But sometimes they have emerged from basic characteristics of the relationship. Sometimes, for example, the information necessary for effective congressional action has been too voluminous, or too complex, or too specialized and abstruse to be collected, grasped, and used by Congress and its agents. Sometimes congressional organization has been inadequate to deal with an administrative bureaucracy. And sometimes the agency, or its supporting interest groups, was able to generate adequate defensive political pressure. ${ }^{\mathbf{2}}$

There have, of course, been many instances in which Congress has had its way; indeed, this is the typical situation, as we would expect it to be. ${ }^{53}$ But one is struck by the fact that there do seem to be quite deep-seated forces that create substantial areas of agency freedom and give the agency effective defensive weapons.

Further, even in legislative-agency relationships not characterized by active administrative resistance to congressional hegemony, there seem to be strong forces that work against really close linkages. Few agencies have ever really been "arms of Congress" for long. But the mysterious subsurface dynamics of the governmental system that make this so have not yet been fully clarified. ${ }^{54}$

5. Relationships between administrative regulation and the courts appear today to have settled into a rather clear and stable pattern. The extreme view urged in the I930's (though perhaps as often as a device of polemics as a serious thesis), that administrative regulation must be brought fully under judicial control-and, indeed, that substantial parts of its tasks must actually be done by the courts-now seems to have been without much foundation; and in recent years, the most commonly heard proposals in this field are the comparatively modest ones that specialized courts take over some kinds of regulatory adjudication and that judicial review be strengthened and enlarged. ${ }^{55}$ And on the other hand, the contrary extreme view, that the

${ }^{51}$ The histories of most agencies, independent and not, yield such examples. 'The CAB, an independent agency that enjoys generally excellent relations with Congress is probably typical. The CAB quite successfully resisted the efforts of the Senate Select Committee on Small Business to get it to change its policy toward the nonscheduled airlines; part of this story is told in the committee's various reports 1951-55. E.g., Senate Select Comm. on Small Business, Annual Report, S. REp. No. x092, 83rd Cong. 2d Sess. (r954).

"sa Again, most agencies' histories yield examples.

${ }^{63}$ Since the constitutional powers of Congress are so overwhelming, and the amount of energy it generates is so vast.

"t A typical example of the "arm of Congress" thesis is found in Evins, Federal Regulatory Commissions-Arms of Congress, 24 ICC PRAC. J. 699 (I957), and in Congressman Evins's remarks in r03 Cong. Rec. 4056 (1957).

${ }^{6}$ There is much in print on the proposals for specialized courts. For surveys and representative viewpoints, see, e.g., Berger, Removal of Iudicial Functions From Federal Trade Commission to a Trade Court: A Reply to Mr. Kintner, 59 Mrch. L. Rev. I99 (1960); Carrow, Administrative Adjudication: Should Its Role be Changed?, 27 Geo. Wash. L. REv. 279 (r959); Davison, An Administrative Court of the United States, 24 GEo. Wash. L. REv. 613 (1956); Gribbon, Should the Judicial Character of the Tax Court be Recognized?, id. at 6r9; Freer, The Case Against the Trade Regulation Section of the 
regulatory process requires virtually complete freedom from judicial intervention, has been disproven. ${ }^{\text {se }}$

The scope of judicial review proper has become rather strikingly limited in doctrine and even more limited in practice. ${ }^{5 T}$ Its most prominent function has emerged as that of policing administrative procedure..$^{58}$ As a device for insuring rationality in administrative determinations, settling problems of agency jurisdiction, and clarifying statutory mandates and policies-functions in which it might well be expected to render vital service-it has been of less importance..$^{59}$

6. In contrast to the comparatively clear and simple picture presented by the relationships between administrative regulation and the courts stands that presented by relationships between administrative regulation and the Presidency. ${ }^{60}$ The experience of the last twenty-odd years strongly suggests that this is the most complex, most changeable, and least understood aspect of the place of administrative regulation among the agencies of government. ${ }^{61}$ About all we can say with real confidence, by way of generalization, is that full integration of regulatory agencies and programs under the presidential hand has proven as illusory a goal and need as has full independence for them, and that by the very nature of the Presidency, no single set of

Proposed Administrative Court, id. at 637; Farmer, An Adninistrative Labor Court: Some Observations on the Hoover Commission Report, id. at 656 . Proposals to strengthen or enlarge judicial review usually do not aim at increasing the scope of review of the evidence beyond substituting the "clearly erroneous" rule for the current "substantial evidence" rule-if, in truth, this would be a very large increase in scope. 4 Davis, op. cit. supra note I, c. 29 . Rather, they more often seek to cut down the areas of unrcviewability, or to give the reviewing court a freer hand in interpreting the law, or to make interim judicial relief more available. See Hearings, supra note $\mathbf{I}$.

${ }^{56}$ This is, of course, in very substantial part because the extremely antagonistic and obstructive attitudes held by some courts in the 1930's toward all regulation, and especially toward administrative regulation for social reform, have collapsed.

${ }^{67}$ Nonspecialists in administrative law are often surprised by how much administrative action is, or can be, made unreviewable under current law and constitutional doctrine, see 4 Davis, op. cit. supra note I, c. 28; and by how much respect the courts give to administrative judgment. E.g., Moog Industries, Inc. v. FTC, 355 U.S. $4^{\text {II }}$ (1958). Specialists quite generally agree that courts, especially those familiar with the field, often are disinclined to exercise their powers, particularly in cases involving agencies that have their confidence.

${ }^{88}$ This is obviously a very sweeping and dangerous generalization. (And how does one mcasure "prominence," anyway?) But it does seem to emerge, as one traces developments of the past twenty-odd years.

${ }^{50}$ As to insuring rationality: (I) There is reason to believe that informal procedures are not only immensely important, I DAvis, op. cit. stupra note 1, cc. I and 4; but arc increasing in importance, Woll, The Development of Shortened Procedure in American Administrative Law, 45 CorNzLL L.Q. 56 (1959); as is regulation by advice and comment. These tend to put agency determinations beyond the reach of judicial review. (2) Agencies very frequently conceal the bases of their determinations in formal proceedings within loose, all-embracing findings that cover without revealing or defining, and hence cannot be effectively reviewed. Similar showings could be made as to jurisdictional problems and as to clarification of statutory mandates and policies.

${ }^{\circ 0}$ A sharp distinction has often been made between the relationships of the Presidency with the independent commissions and those with the agencies in the exccutive branch proper. But as we study the matter further, the distinction seems less and less clear. It is not formal, legal, independent status that divorces agencies from effective presidential control. Here, as in so many instances, the underlying political processes and relationships are vital.

a1 Evidence for this is scattered all through the standard text on the Presidency, Edward S. Conwin, The President: Office and Powers (4th ed. I957), and the many accounts of the Roosevelt Administration. 
organizational arrangements can contain its relationships with the administrative and define the "place" of administrative regulation. ${ }^{62}$

\section{IV}

\section{Administrative Regulation in Operation ${ }^{63}$}

We have offered in the preceding part of this paper some general statements on the place of administrative regulation in government generally-that is to say, on the nature and causes of its relationships with the rest of government. ${ }^{64} \mathrm{We}$ now move closer, and try to do the same for its actual operations. ${ }^{65}$

I. Professor Jaffe has suggested ${ }^{66}$ that there are basic factors inherent in American industrial organization, concepts of regulation, and political machinery that limit substantially the capacity of administrative regulation to exercise the powers of planning and management over industry that its advocates have urged for it. ${ }^{67}$ Some of his theses are particularly relevant to our inquiry, since if they are correctand the evidence for them seems increasingly strong-they establish important limits on the scope of administrative regulation and important requirements for its successful operation. Paraphrased, they are as follows.

First, there are strong American political traditions of representation, of legislative responsiveness to interest groups, and of regulatory statutes granting broad, vague, administrative powers. Further, it is a political fact that for any system of regulation, periods of intense public and legislative interest and of reform activity ultimately give way to periods of quiescence. A consequence is that regulated

\footnotetext{
02 The need of the President for a variety of tools, approaches, and channels of information and influence is made clear in recent studies of the Presidency. E.g., Richard E. Neustadt, Presidential Power: The Politics of Leadership (ig6o). See also a vivid and suggestive study, Rauh, Government by Directive-A Case History, 6r Harv. L. REv. 88 (1947). The plain physical difficulty of full integration appears from the very number and complexity of the organizational structures around the White House. Its political unlikeliness can be inferred from the fact that it has often been proposed, from the time of the report of the President's Committee on Administrative Management in 1937 to the present, but never achieved. Perhaps the moderate suggestions of Dean Landis in his December I96o report to the President-elect on the regulatory agencies will be more successful. JAMEs M. LANDIS, Report on Regulatory Agencies to the President-Elect (I960) [this report has been published as a committee print by the Subcommittee on Administrative Practice and Procedure of the Senate Committee on the Judiciary, 86th Cong., 2d Sess. (r960)]. See the interpretation of this report in McFarland, Landis Report: The Voice of One Crying in the Wilderness, 47 VA. L. Rev. 373 (196r).

${ }^{\circ}$ This part of the present paper draws on studies by the writer of economic regulation of airlines by the CAB. These studies were supported by the Inter-University Case Program and the Social Science Research Council, and the writer wishes to record his gratitude to those organizations. This part is also based, in part, on a study of comments by federal departments and agencies on the Code of Administrative Procedure proposed by the American Bar Assaciation, S. I070, 86th Cong., Ist Sess. (1959). This study was made for a committee of the ABA by a consulting group composed of Dean Leo A. Huard, Professor Rex A. Collings, Jr., to both of whom the writer is greatly indebted, and the writer. See Huard, Collings \& Fick, op. cit. stupra note 16 .

of Emphasizing perhaps to the point of distortion, the political aspects.

os The disclaimers in note 37 supra also apply here.

${ }^{\circ 0} \mathrm{Jaffe}$, The Effective Limits of the Administrative Process: A Reevaluation, 67 Harv. L. Rev. II05 (r954).

${ }^{07}$ He quotes examples of such advocacy from James M. Landis, The Administrative Process $x_{3}$ (1938).
} 
groups, if they are organized and important, can exercise effective pressures to bend regulation their way-perhaps as the legislature creates the regulatory scheme, and certainly later on, as the administrative agency applies the imprecise generalities of the statute in days of obscurity far from the original setting of reform motives and active interest. Industry-orientation in agencies and programs of administrative regulation is not an accident nor an isolated infection, but rather a condition endemic in such surroundings. 88

Second, the dynamic qualities of American industry and industrial organization are incompatible with systems of administrative regulation that are aimed at overall planning and management but do not take management responsibility and are disposed toward "constructive coordination" and toward neat, rational, arrangements that are both orderly and ordered. The Interstate Commerce Commission tried in the $1930^{\circ}$ 's to deal with the new trucking industry within such a system, and the results were unfortunate all around. Air trunkline route certification by the Civil Aeronautics Board has seemed to be almost regularly out of phase with market and technological developments, and the $C A B$ fought aircoach, a vital innovation but one introduced by enterprisers outside the CAB's principal client group. These are two well-known examples; others could be given. ${ }^{69}$

2. However, the more sweeping and radical challenges to the necessity, value, workability, and supposed effects of administrative regulation remain at best unproven, and are in many cases open to very grave doubts. ${ }^{70}$

A number of such challenges have been put forward since New Deal days. One of the most drastic, and one based principally on general social and political theory, is to the effect that virtually any extensive system of government regulation (administrative or otherwise), whether of industries or of other aspects of life, is inconsistent with, and ultimately destructive of, essential conditions for a free society that operates under any meaningful version of the doctrines of representative government and the rule of law. There would be much difficulty, however, in deriving from the experience of our period any clear evidence supporting this view. ${ }^{71}$

A narrow challenge, and one based principally on economic analysis, has been that any industry (and certainly any economy) subjected to a substantial degree of comprehensive administrative regulation is likely to be warped or drastically limited in growth and development. ${ }^{72}$ This challenge, sometimes found in association with the first, tends to be rooted in a general economic philosophy of severe conservatism and heavy reliance on unregulated private enterprise. It is put in various ways, and the arguments for it are complex. Perhaps most commonly, however, it involves

\footnotetext{
${ }^{68}$ His principal specific instances of such orientation are taken from the CAB and the ICC, but his basic analysis would seem to apply across the whole field of administrative regulation.

${ }^{60}$ One source often mentioned is the maritime industry.

${ }^{70}$ Professor Jaffe's paper does not deal with these.

${ }^{71}$ This view is usually asserted by those influenced by the work of Friedrich A. Hayck, notably his The Rond to Serfoom (I944). For a recent criticism especially relevant here, see Jones, The Rule of Law and the Welfare State, 58 CoLuM. L. Rev. 143 (I958).

"See generally the modern "Chicago school" of economists.
} 
either highly restrictive economic assumptions that abstract away from both economic and social realities (e.g., an extremely high degree of purity of competition) or else political views of a Social Darwinist cast. ${ }^{73}$ The first greatly restrict its economic relevance to the current state of affairs; the second, its political. Although this challenge has contributed valuable individual insights (things that are hard to find in the more drastic challenge first described), its validity as a general explanation or description of administrative regulation in operation seems limited.

3. Some broad views of the nature of the American economy have shed light on the operation of administrative regulation of industry, as have some technical economic studies of particular regulatory problems and specific programs.

One such view emphasizes the processes of change and growth in the economy. The system evolves constantly, new industries displace old, new methods of production and transportation appear, new forms of industrial organization are developed, new markets open and new products are devised in a continuing "process of creative destruction."74 The consequences of this are, first of all, that administrative regulation may have great difficulty keeping pace; but, what is perhaps even more important, also that the process in some cases either sweeps away regulatory problems or does regulation's work. Thus, it is argued, the electric street car did more to improve municipal public transportation than any public commissions regulating the horse-cars ever could have.

Such arguments may in concrete instances sometimes be false ones. ${ }^{75}$ But there can be little doubt of the vast and fundamental importance of the general process; and studies of the operation of administrative regulation must take into account, as they must also take into account the slowness of the process, ${ }^{76}$ its generality, which may forestall or distort its effects in specific situations, and the side effects it may have. ${ }^{77}$

Another and somewhat similar broad view is that countervailing forces emerge, from time to time, to perform, more or less automatically, some of the large tasks that regulation is intended to perform but can perform only ineptly and intrusively. Prominent among these are some concerned with preserving the values of free markets. ${ }^{78}$

Of the rather substantial number of more technical economic studies of narrower coverage, only a representative few can be mentioned. Some of these have shown

${ }^{73}$ The political views no doubt often determine the choice of economic assumptions.

7t The phrase is from Joseph A. Schumpeter, Capitalism, Socialism, and Democracy c. 7 (3d ed. I950); and the view is most often urged by those influenced by his work.

${ }_{75}$ That is, the view is a product and part of a grand and exceedingly complex system of socioeconomic thought, see Professor Haberler's essay on Schumpeter in' Henry William Spiegel (Ed.), The DeVeropment of Economic Thought 734 (x952); and it can be legitimately used only in its own proper universe of discourse.

${ }^{70}$ As, indeed, Schumpeter pointed out. Schumpeter, op. cit. supra note 74 , at 83 .

77 Frequently neglected by those who may perhaps appropriately be called "vulgar Schumpeterians."

${ }^{78}$ This view received much stimulation from the success of Professor John Kenneth Galbraith's book, American Capitalism: The Concept of Countervailing Power (I952), and is connected with various of the theses about "the new competition." 
that in commercial air transportation, economic regulation by the Civil Aeronautics Board has entailed serious difficulties when judged by generally-accepted cconomic criteria, and that freedom of entry for new enterprises into the industry and a wider scope for the play of market forces might achieve both better economic results and also better realization of the goals of general public policy and of existing specific statutory policy. ${ }^{79}$ Others have made similar points about the Interstate Commerce Commission's regulation of rail and motor transportation ${ }^{80}$ and about related phases of transportation regulation. ${ }^{81}$ And others have developed telling criticisms of other regulatory efforts. ${ }^{82}$

The findings of the specialized economic studies have not all been unfavorable. Some have discovered little to criticize; and few, if any, suggest that either regulation generally or administrative regulation in particular be abandoned. ${ }^{83}$ But enough that is adverse appears so as to indicate that in the economic sphere, administrative regulation has had no more than uneven and qualified success. The studies do not seem to yield one single explanation of the causes of this outcome; indeed, such an explanation may well be impossible, since the causes seem to be multiple and to vary from agency to agency and program to program. But at least two causes occur very frequently: confused or inadequate statutory mandates, and attempts to do too much. 84

4. In recent years, there has been a great deal of lively controversy centering about the independent regulatory commissions, but involving many related aspects of the general operation of administrative regulation as well. The threads of the controversy are difficult to sort out and appraise, but the viewpoint of this paper suggests comment on a few of them. ${ }^{85}$ Parts of the controversy have been about specific agencies and specific programs; parts have been more general, or have followed specific issues across agency and program lines. ${ }^{86}$ Only a few agencies and

${ }^{70}$ Lucile Sheppard Keyes, Federal Control of Entry Into Air Transpontation (I95I), and $A$ Reconsideration of Federal Control of Entry into Air Transportation, 22 J. AIR L. \& CoM. I92 (I955).

${ }^{80}$ See ERnest W. Williams, JR., The Regulation of Rail-Motor Rate Competition (1958); Nelson, Effects of Public Regulation on Railroad Performance, in $72 \mathrm{D}$ Annual Méting op the American Economic Ass's, Papers and Proceedings, 50 Am. Econ. Rev. 495 (1960).

${ }^{81}$ Most often in connection with questions of competition and industry performance. Sec generally John R. Meyers et al., The Economics of Competition in the Transportation Industries (i959).

${ }^{83}$ See Keyes, Welfare Economics and the Theory of Regulation, 34 Land Econ. 349 (1960); the papers on A Critical Evaluation of Public Regulation by Independent Contmissions in 70TH ANnust. Meeting of the American Economic Ass's, Papers and Proceedings, 48 Am. Econ. Rev. 527 (1958); Petroleum and Natural Gas and the Public Interest, id. at 491; and Improving the Efficiency of the Transportation and Utilities Systems, in 72D Annuat MEETing of THE AMerican Economic Ass'N, Papers nNd Proceedings, 50 Am. Econ. Rev. 495 (1960).

${ }^{83}$ Perhaps the commonest implication, aside from the familiar point that regulatory procedure has been cumbersome and slow, is that regulatory policy has been timid and overly conventional.

${ }^{84}$ Many of the economic studies would agree with Professor Jaffe, supra note 66, at 1134-35, that some comprehensive schemes of regulation might well be contracted down, and that "we should, in short, look for the strategic control, for that control which is the least we can get along with and the most effective for our urgent need." A familiar example of a confused statutory mandate is that given the CAB by the Federal Aviation Act of 1958, 72 Stat. 731, 49 U.S.C. $\$ 1301$ (substantially unchanged from the Civil Aeronautics Act of 1938,52 Stat. 973).

${ }^{85}$ I.e., comment on some broad governmental and political aspects.

${ }^{86}$ Or have been debates over administrative regulation as a whole. 
programs have largely escaped criticism, and on only a few possible issues has general agreement emerged. ${ }^{87}$

Writers oriented to political science and public administration scholarship have long had criticisms of some of the principal characteristics of the independent regulatory commissions. ${ }^{88}$ One of their most fundamental arguments has been that regulation requires strong direction and support from the political leadership of the government (and ultimately strong support from public opinion) if the agency is to make headway against adversely regulated interests and to maintain its independence from them. ${ }^{89}$ Typically, the argument has gone on to assert that the independent commission, by its very independence, tends to be fatally isolated from its natural source of such direction and support, the Presidency. To this is often added the further contention that to be effective, regulation must be coordinated with the work of the executive and the administrative generally, and that independence limits this coordination. ${ }^{00}$

On the other hand, authors writing from other viewpoints (e.g., that of scholarship in administrative law) ${ }^{91}$ have expressed doubts about all this. They have urged, for example, that in general, the administrative process, as it presently exists, can pretty well stand on its own feet; that there is still much merit in some implications of the traditional view that regulation is engaged partly in "quasi-legislative" and "quasi-judicial" tasks that require separation from the Presidency; and especially that in the latter tasks, where individual cases are being decided, considerable separation is required to preserve fairness and impartiality. They have suggested that many problems, such as those of agency feebleness, of domination by regulated groups, and of improper particular influences, are not consequences of independence alone, and in any event, can be dealt with by specific reforms. ${ }^{92}$

This large bundle of issues appears incapable of resolution as things now stand. There are obviously strong arguments from general principle available to all sides. But more refined analyses, and especially more concrete situations, are needed before these arguments can be made to yield defensible answers to specific questions. ${ }^{93}$

Another line of thought is found in the work of a group of critics oriented

${ }^{87}$ All have seemed to agree on the value of democratic responsibility; there has been no enthusiasm for an autonomous bureaucracy.

${ }^{88}$ Marver H. Bernstein, Regulating Business by Independent Commission (1955), summarizcs these. See also Odegard, $A$ Case for Scuttling Regulatory Agencies, Washington Post \& Times Herald, May I, 1960, p. E-I, col. 5 .

80 "This argument is related to the "group theory" of politics, but is independent of it and not necessarily vulnerable to the same criticisms.

${ }^{00}$ This contention was already made in the President's Comm. on Administrative Managenent, REPORT (1937).

01 There is also an immense body of nonscholarly materials.

${ }^{03}$ E.g., much of the testimony in Hearings, supra note I. A thoughtful review of the whole matter is Jaffe, The Independent Agency-A New Scapegoat, 65 YALE L.J. 1068 (1956). An example of this approach to one problem is Note, Ex Parte Contacts With the Federal Communications Commission, 73 Harv. L. Rev. 1178 (Ig60).

${ }^{\circ}$ Some evidence collected by the present writer on economic regulation by the CAB suggests that it is not very clear how closer ties to the Presidency would solve the problems of that agency. 
toward economics and concerned primarily with antitrust problems and with the general relationships between the economic and the political systems. ${ }^{04}$ Sometimes, emphasizing the characteristic complexities and dynamisms of a modern economy, the scope and power of modern corporate groupings, and the weapons at their disposal, this line of thought expresses doubt both about the efficacy of unaided market forces to maintain a sufficiently competitive and unmonopolistic economy, and about the feasibility of constructing systems of administrative regulation adequate to cope with the forces tending toward concentration and control. Outlining a large design, it sees a problem of a grand sort for policy and action in all branches of the political system. ${ }^{95}$

Sometimes, working on a narrower canvas, this view addresses itself to specific agencies and programs of administrative regulation or argues for specific measures. In this vein, it has suggested that administrative regulation has often displaced open competition and the play of market forces without putting viable and effective alternatives in their places, and, indeed, has often become a shelter for restrictionism. Thus, for example, the Civil Aeronautics Board and other specific regulatory agencies and many other specific programs have been critically analyzed, and remedies such as stricter antitrust standards in regulatory statutes and abolition of particular regulatory controls in favor of market forces have been urged.98

The volume and concreteness of the evidence these critics have assembled, the thoroughness and precision of their investigations, and the appeal of the values they urge give their contentions a weight that commands respect. Without venturing a judgment on the final validity of these contentions, we must feel that at the least, these critics have shown that there are vital and unexpectedly difficult problems in this area, and that administrative regulation has dealt with them in a less than fully satisfactory way. ${ }^{97}$

5. Procedure in administrative regulation, like administrative procedure generally, has been, during almost our entire period, the subject of much interest and of much controversy. Reflection on the experience of the period suggests the rightness of this emphasis; procedure is, in truth, a crucial aspect of administrative regulation in many ways and is part of the central complex of the issues and achievements of the system. ${ }^{88}$ A primary and basic point to be made is that procedure is the machinery by which the political power of administrative regulation is formally exercised and, further, that it exerts important influences on informal, indirect, and collateral exercises of this power as well..$^{90}$ Analysis in terms of political power,

Q4 This thought is often another aspect of work of the sort cited supra notes 79-82.

${ }^{95}$ The work of Walton H. Hamilton is classic. E.g., Walton H. Hamiston, The Polrtics op INDUSTRY (I957).

${ }_{90}$ Numerous legal scholars have joined in this.

${ }^{97}$ For an account of the especially unhappy effects commission regulation can have on small business, see Adams, The Regulatory Commissions and Small Business, 24 LAw \& Contemp. Pron. 147 (1959).

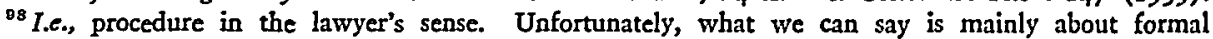
procedure. All too little is known about informal procedure, although some beginnings are bcing made. E.g., Woll, supra note 59 .

${ }^{2 \theta}$ Indeed, procedural requirements set a framework for virtually all administrative regulation. 
an approach used throughout the present paper, is, therefore, peculiarly useful here.

Some of the struggles over procedural questions, especially those of New Deal days, have been clearly recognized as struggles over power. Opponents of administrative regulation have sought to strangle it by getting complicated and restrictive procedural requirements imposed by legislation or the courts. Its supporters have sought both to give it overwhelmingly powerful procedural weapons and to free it from inconvenient procedural restrictions. Extreme statements have been common on both sides. ${ }^{100}$

It is also clear, although perhaps not so generally recognized, that less intense controversies over procedure can have, and many have had, strong elements of power struggle. Thus, for example, a regulatory agency that is required to treat a matter as a formal adjudication, handle it on a separation-of-functions basis, decide it on a record, and issue findings and an opinion in support of the disposition, subject to broad judicial review, is, as compared with an agency not subject to these constraints, a very much less formidable combatant in, say, struggles with interest groups that oppose its regulatory activities and policies. ${ }^{101}$ Not only are innumerable grounds for judicial intervention in its affairs available to be urged against it by such groups, but also its general freedom of maneuver is much cut down and its decisions and decision-making processes are forced more out into the open, where they are more accessible to attacks via public opinion campaigns, technical criticism, legislative investigation, etc.

The devising and operating of effective and acceptable procedures and setting the types and amounts of procedural constraints to be imposed on administrative regulation have presented difficult problems, and the processes of government have struggled painfully over them. A few general comments on what has been accomplished are offered here.

Constitutional limitations and requirements have become rather well settled, although some uncertainties remain and some shifts in the boundaries do occur. ${ }^{102}$ The constitutional minima protecting those subject to the administrative process are rather low, however, leaving numerous questions, some still unsettled, of how much more is required in various circumstances by considerations of fairness and good policy.

A body of general law of administrative procedure has emerged that is more uniform and broader in its coverage than might be supposed in view of the frequently heard assertions that every agency and every program has many unique problems and methods. ${ }^{103}$ In addition, there seems to be a good deal of further

${ }^{100}$ Scattered through a very large part of all the materials we have cited.

${ }^{101}$ This is well-recognized by opponents of "judicialization."

${ }^{102}$ I DAvis, op. cit. supra note I, c. 7, and 4 id. cc. 28 and 29.

${ }^{103}$ E.g., such assertions were very common in agency comments on the ABA Code. See supra note 63. Many of these appeared overstated, but there are, in fact, some significant variations. See the discussion in Westwood, The Davis Treatise: Meaning to the Practitioner, 43 Mrnn. L. Rev. 607 (1959). 
uniformity, in the practice and custom lying beyond the actual law of procedure. ${ }^{104}$ A very detailed body of rules of procedure and practice applying to all agencies and programs may be impossible. ${ }^{105}$ But a rather complete general code of virtually universal coverage seems quite possible; indeed, what appears to be a very satisfactory and workable one has already been proposed. ${ }^{100}$

In many respects-perhaps even in most-administrative procedure as now established functions well. ${ }^{107}$ However, some troubles clearly exist, newly emerged or chronic. ${ }^{103}$ Discussion of these is particularly active just now, and a variety of proposed remedies are in the field. ${ }^{109}$ Some of the proposals appear to be based upon misunderstandings of the nature of the administrative process, or upon a belief that certain troubles or seeming troubles are procedural, when, in actuality, they are produced by other causes. ${ }^{110}$ On the other hand, there are proposals that seem eminently sound and valuable.

The most important and difficult issues of administrative procedure, however, are not simply issues of efficient management of agency business, nor even of clarity and logic in administrative law; rather, they are basic issues of politics and government.

\section{CoNCLUSION}

This paper has been an attempt to get a general view of some of the broad governmental and political processes that have affected administrative regulation in the last twenty-odd years; then to analyze the effects these have had on the problems, issues, goals, and achievements of administrative regulation during that time. That is to say, it has been an attempt to locate administrative regulation in these processes and to discover something about its relationships with them. The inquiry has produced a good many specific conclusions on both these matters. But, most of all, we end it with a heightened sense of how very much a part of the political order administrative regulation is.

\footnotetext{
${ }^{104}$ This also appeared in agency comments on the ABA Code, supra note 63 , and in the House Government Operations Committee study, supra note $\mathrm{r}$.

${ }^{105}$ See, e.g., the limited recommendations of the President's Conference on Administrutive ProCEDURE, REPORT (1955).

${ }^{200}$ I.e., the ABA Code, with the amendments suggested by the consulting group that studied agency comments on it, supra note 63 .

${ }^{102}$ Though there are few broad surveys, across the whole field, on which firm judgment can be based.

${ }^{208}$ E.g., ex parte contacts, delay, volume and expense, inadequate policy development, ctc.

${ }^{100}$ See, e.g., materials cited in notes $I, 16,45,55,59,66,88,92$, and 107 supra. See also Hector, Problems of the CAB and the Independent Regulatory Commissions, 69 YALE L.J. 931 (1960) [this report has been published as a committee print by the Senate Committee on Government Organization, 86th Cong., 2d Sess. (I960)].

${ }^{110}$ Such as those discussed in pt. III of the present paper.
} 